\title{
Interindividual Size Heteromorphism of NOR and Chromosomal Location of 5S rRNA Genes in Iheringichthys labrosus
}

\author{
Rafael Augusto de Carvalho and Ana Lúcia Dias* \\ Universidade Estadual de Londrina; Departamento de Biologia Geral; CCB; anadias@uel.br; C. P. 6001; \\ 86051-970; Londrina - PR - Brasil
}

\begin{abstract}
Twenty-five specimens of Iheringichthys labrosus from the Capivara Reservoir were analysed cytogenetically. AgNORs were detected in a pair of ST chromosomes, in the telomeric region of the long arm. Some individuals showed size heteromorphism of this region between homologous chromosomes. Treatment with $\mathrm{CMA}_{3}$ displayed $G C$-rich regions corresponding to the AgNOR pair, plus other fluorescent staining. In situ hybridization by fluorescence (FISH) with the 18S rDNA probe showed only one pair of stained chromosomes, confirming the heteromorphism observed with $\mathrm{AgNO}_{3}$ and $\mathrm{CMA}_{3}$ in some individuals. The $5 \mathrm{~S}$ rDNA probe revealed telomeric staining on the long arm of a pair of chromosomes of the ST-A group, probably different from the NOR pair.
\end{abstract}

Key words: Fish chromosome, AgNOR, in situ hibridization, chromomycin $\mathrm{A}_{3}$, heteromorphism

\section{INTRODUCTION}

Ribosomal cistrons are organized in multiple copies that are repeated in tandem throughout the cellular genome. Two different arrangements are known: one that contains 45S ribosomal DNA (rDNA) which codes for $28 \mathrm{~S}, 5.8 \mathrm{~S}$ and $18 \mathrm{~S}$ ribosomal RNA (rRNA), and another that contains $5 \mathrm{~S}$ rDNA. The nucleolar organizing regions (NORs), which correspond to the 45S rDNA, can be easily visualized by silver nitrate (AgNOR) staining, which is a relatively simple method. However, the visualization of 5S rDNA sites requires more specific techniques, such as fluorescence in situ hybridization (FISH).

The fluorochromes that preferentially stain GCrich regions, such as mithramycin and chromomcyin $\mathrm{A}_{3}\left(\mathrm{CMA}_{3}\right)$, have also been widely used in chromosome preparations of fish to demonstrate the location of NORs, because according to Salvadori et al. (1995), these regions are associated with DNA families rich in GC bases. More recently, FISH with rDNA probes has been utilized with precision to determine the exact location and number of ribosomal cístrons. In the family Pimelodidae, the 18S rDNA probe has been utilized in Zungaro zungaro (Swarça et al., 2001a), Pinirampus pirinampu (Swarça et al., 2001b) and some species of Pimelodus (Souza et al., 2004), among others. The 5S rDNA genes consist of highly conserved sequences of 120 base pairs (Pendás et al., 1994) and have been studied in fish such as Prochilodus lineatus (Jesus and Moreira-Filho, 2003), Astyanax scabripinnis (Marco-Ferro et al., 2001), some species of

\footnotetext{
* Author for correspondence
} 
Parodon (Vicente et al., 2001) and Hoplias (Born and Bertollo, 2000).

This work aimed to analyse the NORs of Iheringichthys labrosus (Siluriformes, Pimelodidae), using different treatments: $\mathrm{AgNO}_{3}$, $\mathrm{CMA}_{3}$ and FISH with the 18S rDNA probe, and to determine the location of $5 \mathrm{~S}$ rDNA genes.

\section{MATERIALS AND METHODS}

Twenty five specimens of Iheringichthys labrosus collected in two different municipalities near the Capivara Reservoir in Brazil were used in the present study. This included 15 individuals (9 females and 6 males) from Sertanópolis (PR, Brazil) and 10 individuals (5 females, 4 males and one of indetermined sex) from Porecatu (PR, Brazil). The specimens analysed were deposited in the collection of the Museu de Zoologia da Universidade Estadual de Londrina.

Mitotic chromosome preparations were obtained according to Bertollo et al. (1978). The nucleolus organizer regions (NORs) were analysed by the technique of Howell and Black (1980) and the treatment with fluorochrome chromomycin A3 followed the technique of Schmid (1980). The 18S rDNA (1700pb), from the fish Oreochromis niloticus and 5S rDNA (200 pb), from the fish Leporinus elongatus, were used for in situ hybridization and labeled with biotin-14-dATP by nick translation (Gibco cat $\mathrm{N}^{\circ}$ 18247-015), according to the manufacturer's instructions. The hybridization and post-hybridization steps and the detection of the chromosomal signals were carried out according to Swarça et al. (2001b).

\section{RESULTS AND DISCUSSION}

The karyotype of I. labrosus from the Capivara Reservoir has been described by Carvalho and Dias (2005), in which all the individuals showed $2 n=56$ chromosomes with a distribution of $26 \mathrm{M}+12 \mathrm{SM}+6 \mathrm{ST}+12 \mathrm{~A}$, and some of them had a supernumerary microchromosome, with inter- as well intraindividual variation. The AgNOR was observed in I. labrosus from the Capivara Reservoir in individuals from both Sertanópolis and Porecatu, in a pair of subtelocentric (ST) chromosomes with telomeric staining on the long arm. Size heteromorphism of this region was detected between homologous chromosomes of some individuals, and homomorphic NORs were also observed, showing interindividual variation both in males and females (Figs. 1a-b). The same location of NOR was reported for other population of I. labrosus (Vissotto et al., 1999), demonstrating the conservation of this region in chromosomes of this species, independent of their habitat; however, the heteromorphism was not observed.

Treatment with the fluorochrome $\mathrm{CMA}_{3}$, which preferentially stained regions rich in GC base pairs, showed correspondence with AgNOR sites in I. labrosus, and also demonstrated a homomorphic pair in some individuals and a heteromorphic pair in others. Besides the NOR pair staining positive with $\mathrm{CMA}_{3}$, other fluorescent regions could be seen (Figs. 1c-d). In fish of the family Pimelodidae, the NOR has been frequently found to be fluorescent after $\mathrm{CMA}_{3}$ treatment because of its association with GC-rich heterochromatin regions (Swarça et al., 2001a, 2001b; Borin and Martins-Santos 2002; Souza et al., 2004).

The utilization of the 18S rDNA probe in FISH analysis of chromosome preparations of $I$. labrosus showed the presence of rRNA genes in the terminal portion of a pair of ST chromosomes, on the long arm. Some individuals demonstrated a pair of homomorphic staining chromosomes, while others showed a pair of heteromorphic staining chromosomes (Figs. 2a-b). Therefore, this variation in NOR size in I. labrosus from the Capivara Reservoir was due to a variable number of rDNA genes. Mechanisms such as unequal crossing-over, transpositions or other rearrangements including deletions and/or duplications, involve segments of homologous chromosomes, and are, thus, frequently attributed to mechanisms related to structural modifications of NORs (Galleti-Jr et al., 1995; Castro et al., 1998).

Size heteromorphism of the AgNOR was also seen in other species of the family Pimelodidae, such as Zungaro zungaro, Pinirampus pirinampu (Swarça et al. 2001a, 2001b), Pimelodus sp., P. argenteus, $P$. mysteriosus, $P$. maculatus (Souza et al., 2004) and the FISH also confirmed that this heteromorphism was a structural event due to the accumulation of rDNA genes in one of the two homologous as demonstrated in the present work. 

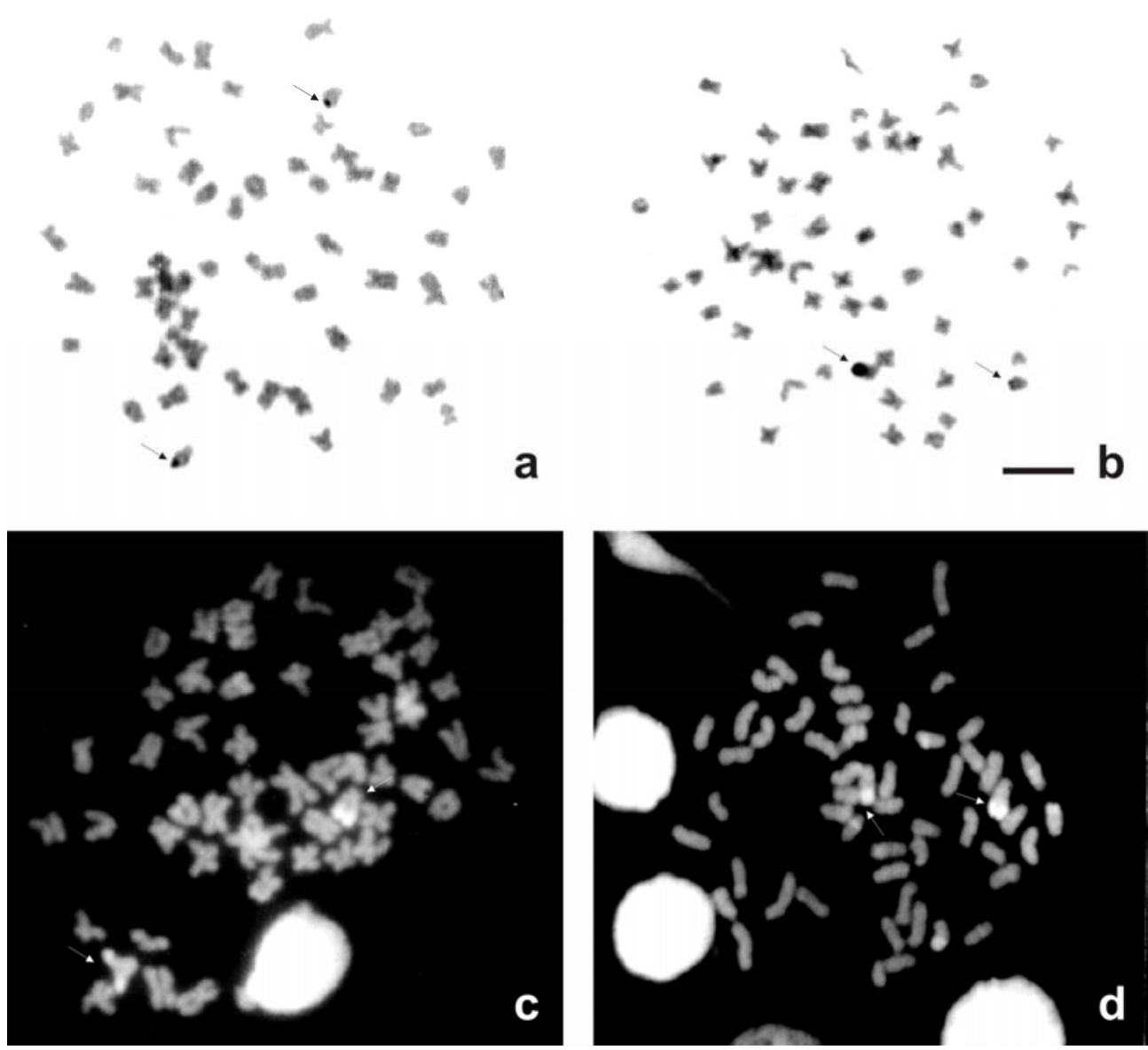

Figure 1 - Somatic metaphases of Iheringichthys labrosus submitted to treatments with silver nitrate $(\mathrm{a}, \mathrm{b}), \mathrm{CMA}_{3}(\mathrm{c}, \mathrm{d})$ The arrows indicate NOR-bearing chromosomes. Scale bar $=10 \mu \mathrm{m}$

No other additional staining was observed with the $18 \mathrm{~S}$ rDNA probe, as seen with $\mathrm{CMA}_{3}$ treatment, demonstrating the existence of a simple system of NOR, which indicates that other fluorescent staining observed after $\mathrm{CMA}_{3}$ treatments must correspond to $\mathrm{GC}$-rich heterochromatin regions.

Fluorescence in situ hybridization with the $5 \mathrm{~S}$ rDNA probe in I. labrosus from the Capivara Reservoir displayed telomeric staining on the long arm of a pair of chromosomes of the ST-A group (Fig. 3), probably different from the NOR pair. However more studies should be carried through to confirme this fact. The location of 5S rDNA genes on chromosomes different than those bearing $45 \mathrm{~S}$ rDNA (non-syntenic) appeared to represent a primitive condition in genomic organization and chromosomal evolution (Martinez et al., 1996). According to Martins and Galleti-Jr (1999), this non-synteny would be important in preventing undesirable translocations of $5 \mathrm{~S}$ sequences within $45 \mathrm{~S}$ genes, which could occur easily if these clusters were linked in the same chromosome.

In the family Pimelodidae, Marques (2002) determined the chromosomal location of 5S rDNA genes of Conorhynchos conirostris on the short arm of a pair of acrocentric-type chromosomes, in which $18 \mathrm{~S}$ rDNA was located on the long arm of a subtelocentric pair.

Swarça (2003) studied 5S rDNA genes in Steindachneridion scripta, Steindachneridion $\mathrm{sp}$. and Pseudoplatystoma corruscans and the position of these genes in these three species was determined to be on chromosome pairs morphologically distinct from NOR-bearing ones. 

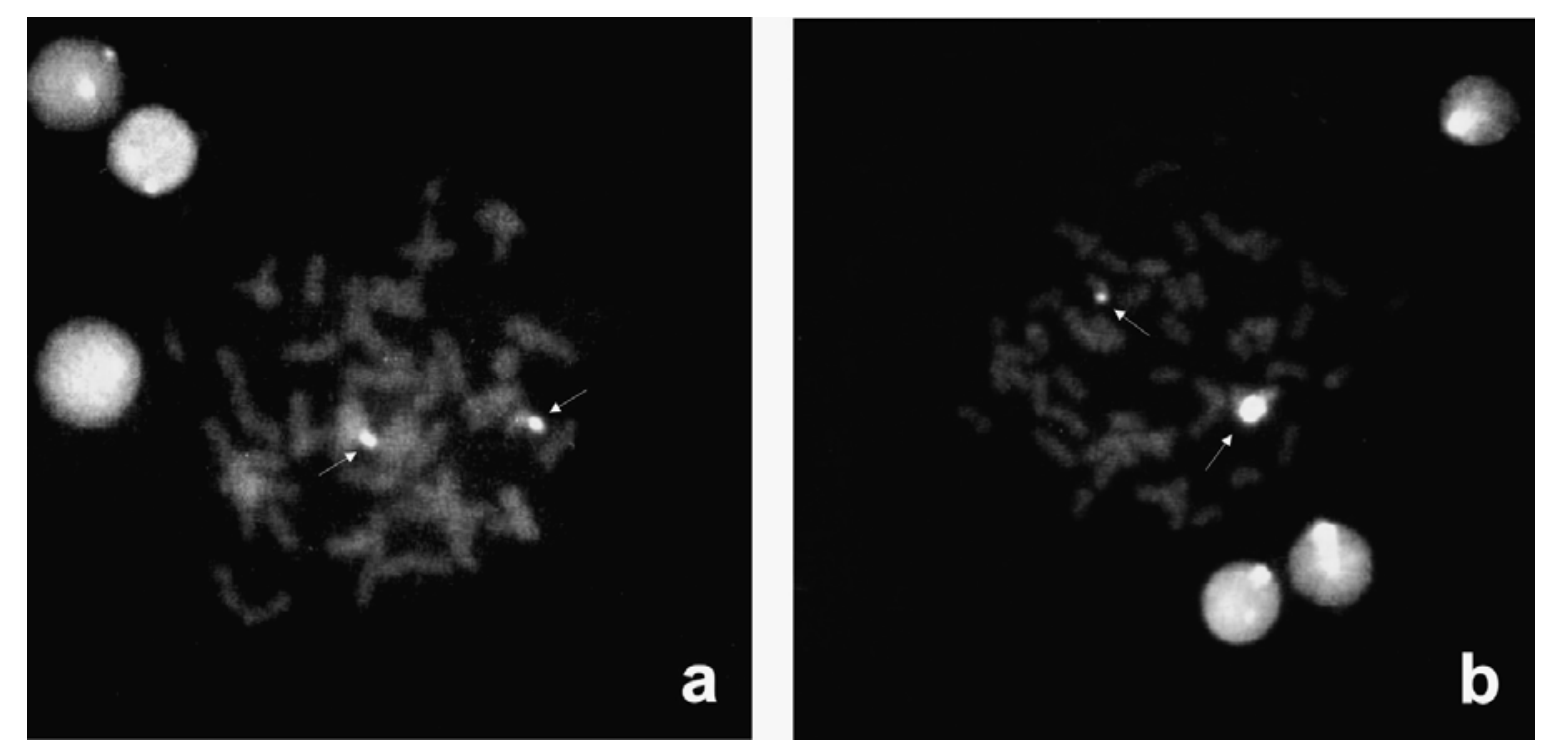

Figure 2 - Somatic metaphases of Iheringichthys labrosus submitted to treatment with 18S rDNA probe (a, b).

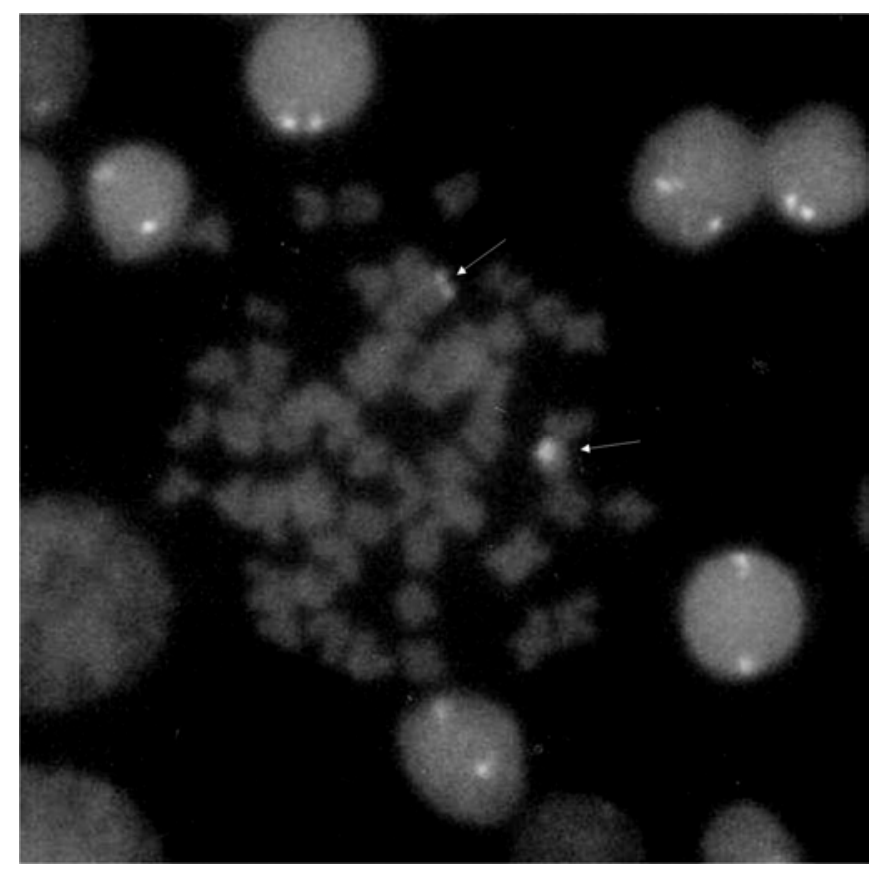

Figure 3 - Somatic metaphase of Iheringichthys labrosus submitted to treatment with 5S rDNA probe. The arrows indicate the location of 5S rDNA genes.

This is the first study to provide cytogenetic data on the localization $18 \mathrm{~S}$ and $5 \mathrm{~S}$ rDNA genes in a population of I. labrosus, showing that the size heteromorphism of NOR observed represents a true polymorphism, since it involves variations in the copy number of genes in homologous chromosomes.

\section{ACKNOWLEDGEMENTS}

The authors are grateful to CAPES for their financial support and to Dr. Albert Leyva for his help in the preparation of the manuscript. 


\section{RESUMO}

Foram analisados citogeneticamente vinte e cinco indivíduos de Iheringichthys labrosus da Represa Capivara. As AgNORs foram detectadas em um par de cromossomos ST na região telomérica do braço longo. Em alguns exemplares machos e fêmeas foi observado um heteromorfismo de tamanho desta região entre cromossomos homólogos. O tratamento com $\mathrm{CMA}_{3}$ exibiu regiões ricas em GC correspondentes ao par da NOR e outras marcações fluorescentes. A hibridação in situ por fluorescência (FISH) com a sonda de DNAr 18S mostrou somente um par de cromossomos marcados, confirmando o heteromorfismo observado com $\mathrm{AgNO}_{3}$ and $\mathrm{CMA}_{3}$ em alguns indivíduos. A sonda de DNAr 5S revelou marcação telomérica no braço longo de um par de cromossomos do grupo ST-A, provavelmente diferente do par da NOR.

\section{REFERENCES}

Bertollo, L.A.C., Takahashi, C.S. and Moreira-Filho, O. (1978), Cytotaxonomic considerations in Hoplias lacerdae (Pisces, Erythrinidae). Brazilian Journal Genetics, 1: 103-120.

Borin, L.A. and Martins-Santos, I.C. (2002), Cytogenetic aspects in species of the genus Pimelodus (Pisces, Siluriformes, Pimelodidae) of the river Paraná basin. Cytologia, 67: 199-204.

Born, G.G. and Bertollo, L.A.C. (2000), An XX/XY sex chromosome system in a fish species, Hoplias malabaricus with a polymorphic NOR-bearing $\mathrm{X}$ chromosome. Chromosome Research, 8: 111-118.

Carvalho, R. and Dias, A.L. (2005), Cytogenetic characterization of $\mathrm{B}$ chromosomes in two populations of Iheringichthys labrosus (Pisces, Pimelodidae) from the Capivara Reservoir (Paraná, Brazil). Caryologia, 58: 269-273.

Castro J., Sánchez, L. and Martinez, P. (1998), Analysis of the inheritance of NOR size variants in brown trout (Salmo trutta). Journal of Heredity, 89: 264-266.

Galetti-Jr P.M., Mestriner, C.A., Monaco, P.J. and Rasch, E.M. (1995), Post-zygotic modifications and intra and interindividual nucleolar organizing region variations in fish: report of a case involving Leporinus friderici. Chromosome Research, 3: 285290.

Howell, W.M. and Black, D.A. (1980), Controlled silver staining of nucleolus organizer regions with a protective colloidal developer: a one-step method. Experientia, 36: 1014-1015.
Jesus, C. M. and Moreira-Filho, O. (2003), Chromosomal location of $5 \mathrm{~S}$ and $18 \mathrm{~S}$ rRNA genes in Prochilodus lineatus (Characiformes, Prochilodontidae). Caryologia, 56: 281-287.

Marco-Ferro, D.A., Néo, D.M., Moreira-Filho, O. and Bertollo, L.A.C. (2001), Nucleolar organizing regions, 18S and 5S rDNA in Astyanax scabripinnis (Pisces, Characidae): populations distribution and functional diversity. Genetica, 110: 55-62.

Marques, M.B.A. (2002), Estudos citogenéticos em Conorhynchos conirostris e Lophiosilurus alexandrii (Pisces, Siluriformes), espécies endêmicas do rio São Francisco. Master Dissertation, Universidade Federal de São Carlos, São Carlos.

Martinez, J.L., Morán, P., Garcia-Vazquez, E. and Pendás, A.M. (1996), Chromosomal localization of the major and 5S rRNA genes in the European eel (Anguilla anguilla). Cytogenetic Cell Genetic, 73: 149-152.

Martins, C. and Galetti-Jr., P.M. (1999), Chromosomal localization of 5S rDNA genes in Leporinus fish (Anostomidae, Characiformes). Chromosome Research, 7: 363-367.

Pendás, A.M., Morán, P., Freije, J.P. and GarcíaVásquez, E. (1994), Chromosomal mapping and nucleotide sequence of two tandem repeats of Atlantic salmon 5S rDNA. Cytogenetic and Cell Genetic, 67: 31-36.

Salvadori, S., Deiana, A. M., Coluccia, E., Floridia, G., Rossi, E. and Zuffardi, O. (1995), Colocalization of (TTAGGG) $)_{\mathrm{n}}$ telomeric sequences and ribosomal genes in atlantic eels. Chromosome Research, 3, 54-58.

Schmid, M. (1980), Chromosome banding in Amphibia IV. Differentiation of G-C and A-T rich chromosome regions in Anura. Chromosoma, 77: 83-103.

Souza, L., Swarça, A.C. and Dias, A.L. (2004), Analysis of the nucleolus organizer regions in 5 species of the genus Pimelodus (Siluriformes, Pimelodidae), using $\mathrm{AgNO}_{3}, \mathrm{CMA}_{3}$ and FISH with the 18S rDNA probe. Caryologia, 57: 145-151.

Swarça, A.C. (2003), Contribuição à citogenética dos Pimelodidae de grande porte: estudos cariotípicos em 4 espécies do "subgrupo" Sorubiminae. Doctoral Thesis. Universidade Federal do Paraná, Curitiba.

Swarça, A.C., Cestari, M.M., Giuliano-Caetano, L. and Dias, A.L. (2001a), Cytogenetic characterization of the large South American siluriform fish species Zungaro zungaro (Pisces, Pimelodidae). Chromosome Science, 5: 51-55.

Swarça, A.C., Giuliano-Caetano, L., Vanzella, A.L.L. and Dias, A.L. (2001b), Polymorphism of rRNA genes in Pinirampus pirinampu (Pisces, Pimelodidae) detected by in situ hybridization. Cytologia, 66: 275-278. 
Vicente, V.E., Jesus, C.M. and Moreira-Filho, O. (2001), Chromosomal localization of $5 \mathrm{~S}$ and $18 \mathrm{~S}$ rRNA genes in three Parodon species (Pisces, Parodontidae). Caryologia, 54: 365-369.

Vissotto P.C.; Foresti, F. and Oliveira, C. (1999), Supernumerary chromosomes in two species of the family Pimelodidae (Teleostei, Siluriformes). Chromosome Science, 3: 9-13.

Received: May 24, 2005; Revised: November 23, 2005; Accepted: August 29, 2006. 